\title{
Historical review of lighthouse design under wind load: the Ile Vierge lighthouse
}

\author{
Nathalie Domede ${ }^{1}$, Luisa Pena ${ }^{1}$, Nicolas Fady ${ }^{2}$
}

1: LMDC, Université de Toulouse, INSA/UPS Génie Civil,135 Avenue de Rangueil, 31077

Toulouse cedex04, France,

2: CEREMA/DTecEMF/TI Technopole Brest Iroise, BP5 29280 Plouzané, France

N.DOMEDE ORCID ID 0000-0002-3791-0820

Keywords: lighthouse, wind load, masonry structures, diagnosis

\begin{abstract}
The purpose of the study presented here is to describe the design method used by engineers in the $19^{\text {th }}$ and early $20^{\text {th }}$ centuries to size lighthouses structures, and to compare them with current European standards. The historical information presented here is derived from two sources in particular: the archives of the lle Vierge lighthouse, which was built at the northern tip of Brittany between 1897 and 1902, and the scientific journals, books and courses available at that time. Firstly, the article describes the structure of the lle Vierge lighthouse which is the tallest stone lighthouse in Europe. The wind load acting on lighthouses and chimneys was formulated in France by L. Fresnel in 1825. Fresnel's work is compared to WJ M. Rankine's theory used in the UK. The safety coefficients applied with respect to the stability of the towers in France and the UK in the $19^{\text {th }}$ century are compared. On the occasion of the construction of the lle Vierge lighthouse, the masonry strength under wind loads led to discussion among engineers of the French lighthouse authorities. They also worried about the risk of excessive oscillations of the towers, which could cause a dysfunction of the lamp. Thirdly, the standard wind action defined in Eurocode 1 is applied to the lle Vierge lighthouse. Calculation results are given. A comparative analysis of the ancient and modern methods is presented. Overall, this historical research shows that the designers of lighthouses in the $19^{\text {th }}$ century had the same objectives as today: to build strong, durable structures in which deformations under loads are compatible with serviceability.
\end{abstract}

\section{INTRODUCTION}

This paper is part of civil engineering research on the structural diagnosis of the masonry lighthouses in Brittany (western France). Most of them were built between 1830 and the early 20th century. Some of these buildings present disorders such as visible cracks on the walls and corrosion on the metal parts, which call their stability and durability into question.

There are about 150 tall lighthouses in France, including about thirty at sea. The vital role of these constructions in safe navigation, and their cultural and heritage value mean that these structures must be 
maintained in service as long as possible. To help achieve this, a diagnosis methodology is being developed on the lle Vierge lighthouse described at the beginning of this paper. The first step of this methodology concerns historical research on masonry towers. This research makes sense today because, while research works on the optical apparatus of lighthouses are extremely numerous and detailed, those on the civil engineering of lighthouses are rare.

The historical and mechanical research presented here focuses on the method used by $19^{\text {th }}$ century engineers to calculate the masonry towers under wind action. The historical information presented is derived from the archives of the lle Vierge lighthouse and from scientific journals, books and courses available at that time and during the previous 140 years.

The construction of the lle Vierge lighthouse, a building of exceptional height for the time, raised questions and caused debate among the engineers of the French lighthouse authority (Service des Phares et Balises). Their letters, available in the departmental archives of Finistère (the western end of Brittany), testify to this. They discussed the wind velocity and wind pressure on the structure, the criteria for sizing the tower, and the choice of materials to ensure its durability. They shared the feedback from the lighthouses already built in France, but not only in France. The assumptions and calculation methods used by engineers in England for the design of lighthouses and chimneys were also consulted and analysed. It was only after a long and fruitful comparative analysis of the practices of both, which lasted from June 1896 to March 1897, that the project for the construction of the lle Vierge lighthouse was definitively adopted, in its third version, and that construction could start. It is a synthesis of this analysis that is presented in this article.

Firstly, a synthetic description of the lle Vierge lighthouse is presented. Secondly, the article focuses on the calculation methods for the wind action on lighthouse towers and chimneys applied by $19^{\text {th }}$ century engineers in France and England. Then, the wind action defined by the current European standards of Eurocode 1 (EC 1) is applied to the lle Vierge lighthouse. A comparative analysis of the old and modern calculation methods completes the study.

\section{THE ILE VIERGE LIGHTHOUSE}

The lle Vierge is an island located $1.5 \mathrm{~km}$ from the northern coast of Brittany, the most westerly region of France (Fig. 1), at the entrance of the Channel. This maritime corridor between France and England hosts exceptionally dense maritime traffic as it is the unavoidable passage between the Atlantic Ocean and the North Sea. This is why an impressive number of lighthouses have been built along the Channel coast, both on the French side and on the English side (about 100 tall lighthouses in total).

On the lle Vierge, two lighthouses were built, the first in 1845, the second between 1897 and 1902 (Fig.2). It is the latter lighthouse that is the subject of this paper. Its focal plane had to rise $75 \mathrm{~m}$ above the highest tides, in accordance with the Ministerial decision of August 22, 1896 [A1], so the tower had to be $82 \mathrm{~m}$ high (84.50 $\mathrm{m}$ at the top of the lantern), $10 \mathrm{~m}$ more than the highest French lighthouse of the time [1]. The lle Vierge lighthouse thus became the most powerful lighthouse of the 60 major lighthouses existing on the French coast of the Atlantic Ocean when it was first lit on March 1, 1902, [2] and it remains the highest stone lighthouse in Europe today. The University of North Carolina, USA, classifies it as "the tallest traditional masonry lighthouse ever built" [3]. It has been listed as a French historical monument since May 23, 2011.

The geometry of the lighthouse was designed by A. Considère and G. Pigeaud, both engineers of the Ecole des Ponts et Chaussées, working for the French lighthouse authority (Service des Phares et Balises) led by L. Bourdelles. The architecture was clearly the work of engineers concerned with the functionality of the 
lighthouse, its robustness, its durability and its cost, as evidenced by the letters they exchanged during the year 1896.

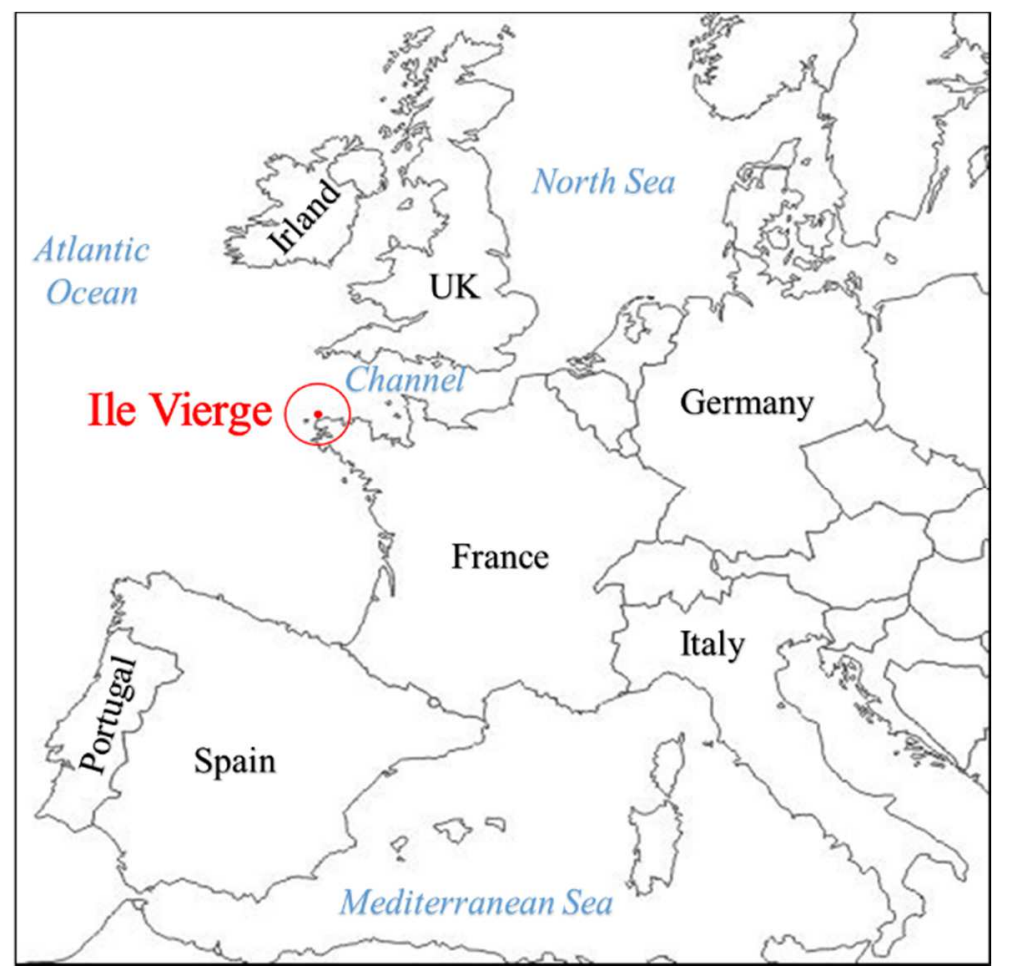

Figure 1 - Location of Ile Vierge
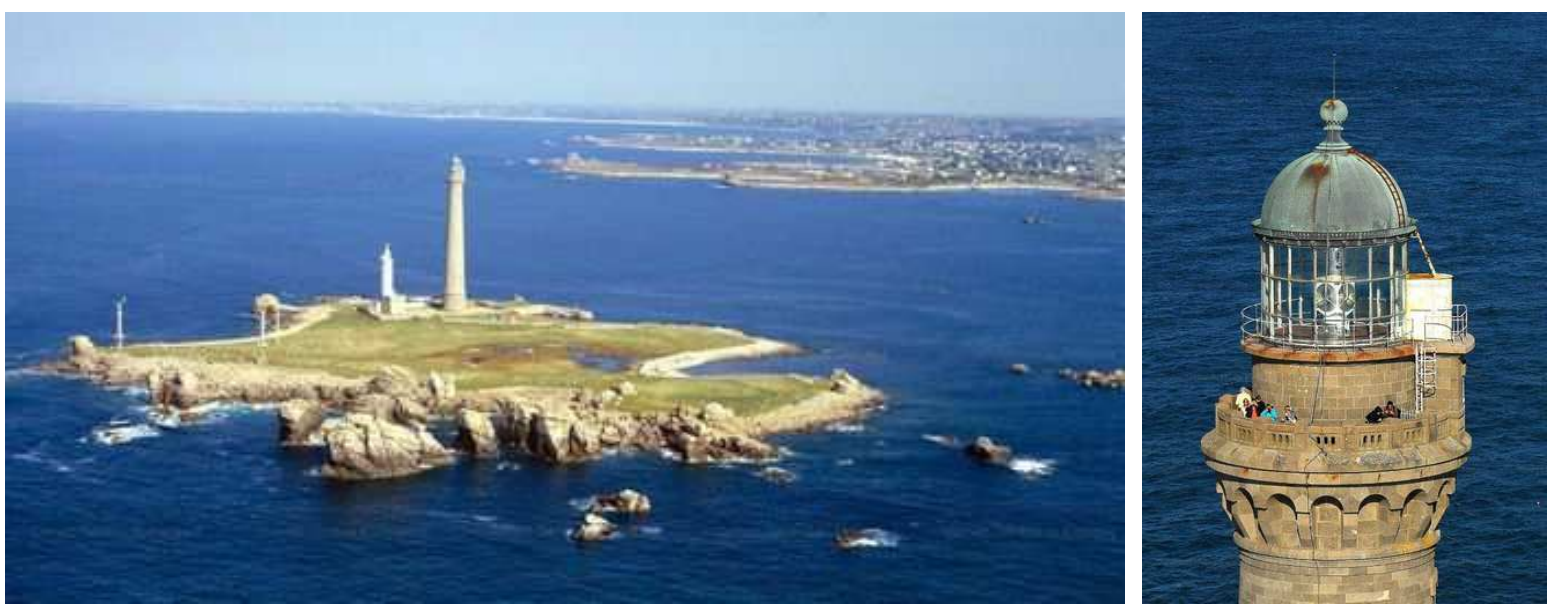

Figure 2 - Ile Vierge lighthouse. (a) Left: aerial view of the island - (b) Right: aerial view of the lantern room and the balcony around its basement wall [A3] [A4].

(a) The optical apparatus

Originally, the optical apparatus consisted of optics each having an Aüer burner [A5] and two $3.55 \mathrm{~m}$ high Fresnel lenses [4] (Fig. 3). The optical apparatus was supported by a base resting in a mercury bath to limit friction. The lantern protecting the optical apparatus was a cylindrical metal structure of $5 \mathrm{~m}$ inner diameter, glazed in its vertical part ( $4.20 \mathrm{~m}$ high), and topped by a dome. 

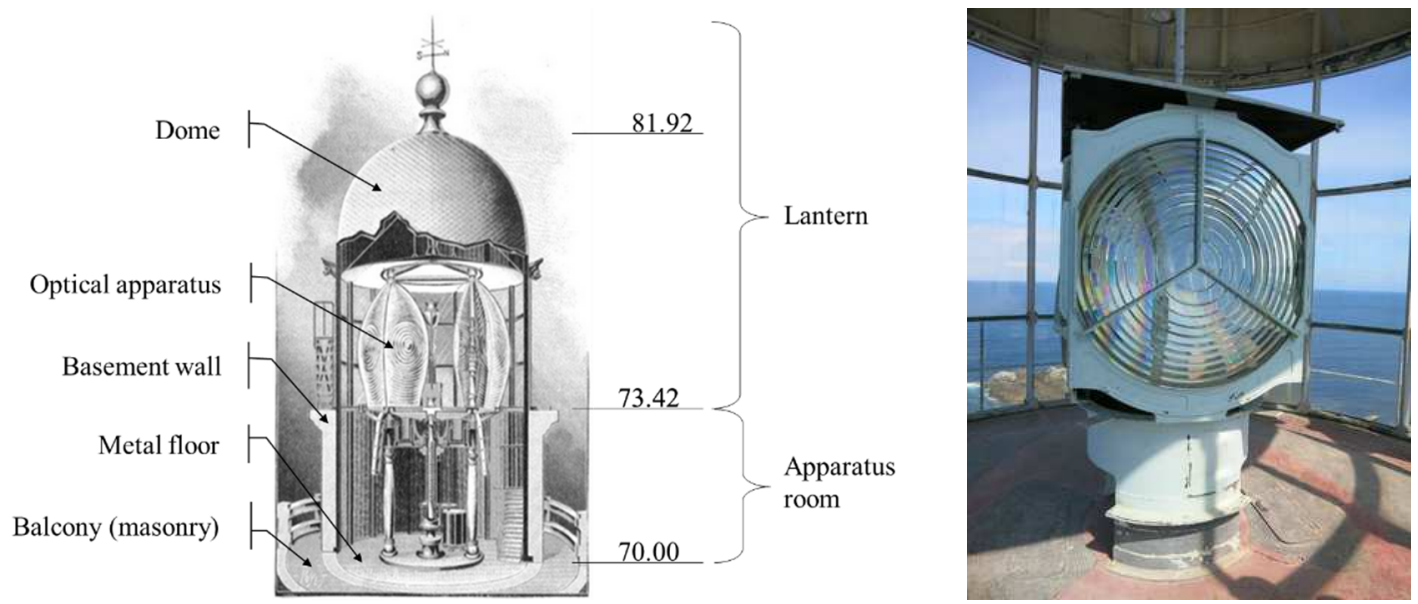

Figure 3 - lle Vierge lighthouse. The optical apparatus. Left: the original lens [2] - Right: the current lens. The levels are in metres, the 0.00 reference level being the ground at the foot of the tower.

This structure is anchored in a $50 \mathrm{~cm}$ thick cylindrical wall made of kersantite (local magmatic rock) stone masonry, called the "basement wall" (Fig.3). This perimeter wall delimits a cylindrical room ( $3.40 \mathrm{~m}$ high and 5 $\mathrm{m}$ of inside diameter) that houses the machine of the optical apparatus. Its floor is metallic.

(b) The tower

The tower is a stone masonry structure with a circular cross section ( $15 \mathrm{~m}$ at the bottom, $7 \mathrm{~m}$ minimum at level 65.80. Fig.4), like about half of the tall French lighthouses, the others being of square or octagonal section [5]. The square shape, more affected by wind load, was restricted to low-rise towers. The internal void space of the towers is almost always cylindrical [6]. In the case of the lle Vierge lighthouse, it has a constant diameter $(5 \mathrm{~m})$ and contains the 395 stone steps giving access to the service room of the lighthouse keeper (Fig. 4).

The entire structure between the 0.00 and 73.42 levels is in granite (inner side) and kersantite masonry (exterior side of the tower and the entire basement wall). The inner side of the wall of the tower below the service room is lined with a brick wall covered with blue opaline plates (Fig. 5). Under the Apparatus room is the service room of the lighthouse keeper (who was housed in the old, smaller lighthouse of the lle Vierge). The floor of this room, built in March 1900, is in reinforced cement following the Hennebique technique, patented 8 years earlier. 

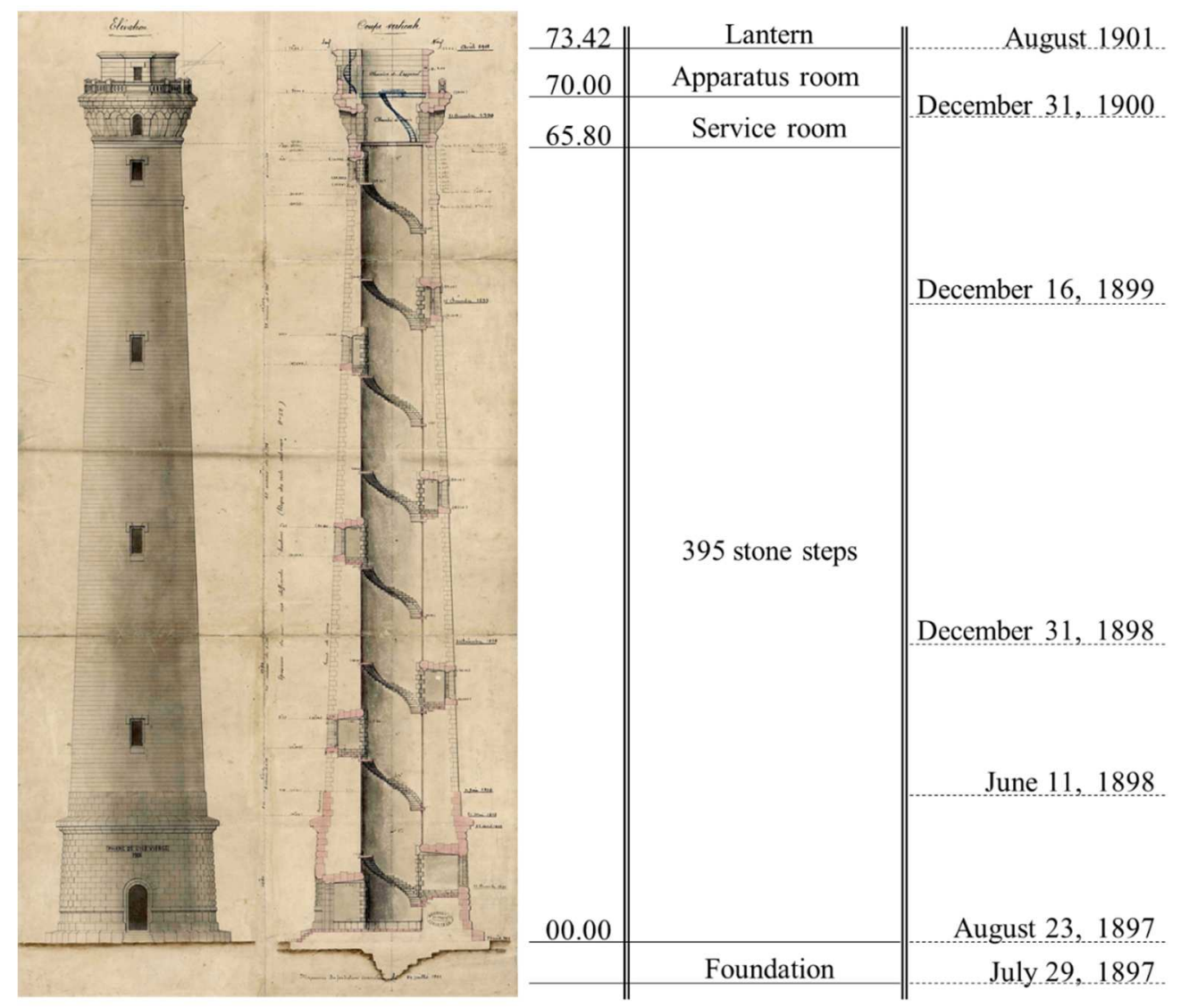

Figure 4-Plan of the tower [A6]

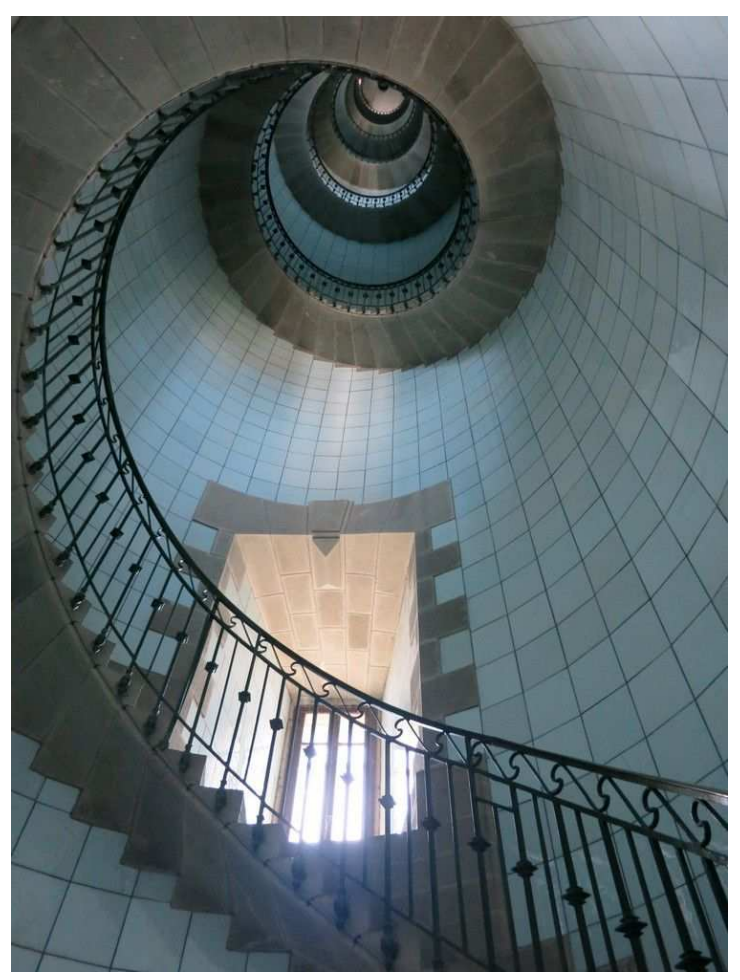

Figure 5-Internal view of the lighthouse 
(c)

Two types of stone were used: granite and kersanton. They were already used together in the Pierres Noires lighthouse (circular tower $28 \mathrm{~m}$ high completed in 1871) and the Eckmühl lighthouse (square tower $65 \mathrm{~m}$ high completed in 1897), also located at the western end of Brittany [7]. The internal facing of the cylinder, not exposed to weathering, was built with granite rubble extracted from the ground of the island near the lighthouse [A1] [A7] (Fig.6). The kersanton stones were used for the outer facing of the tower and the entire basement wall of the lantern at the top of the tower.

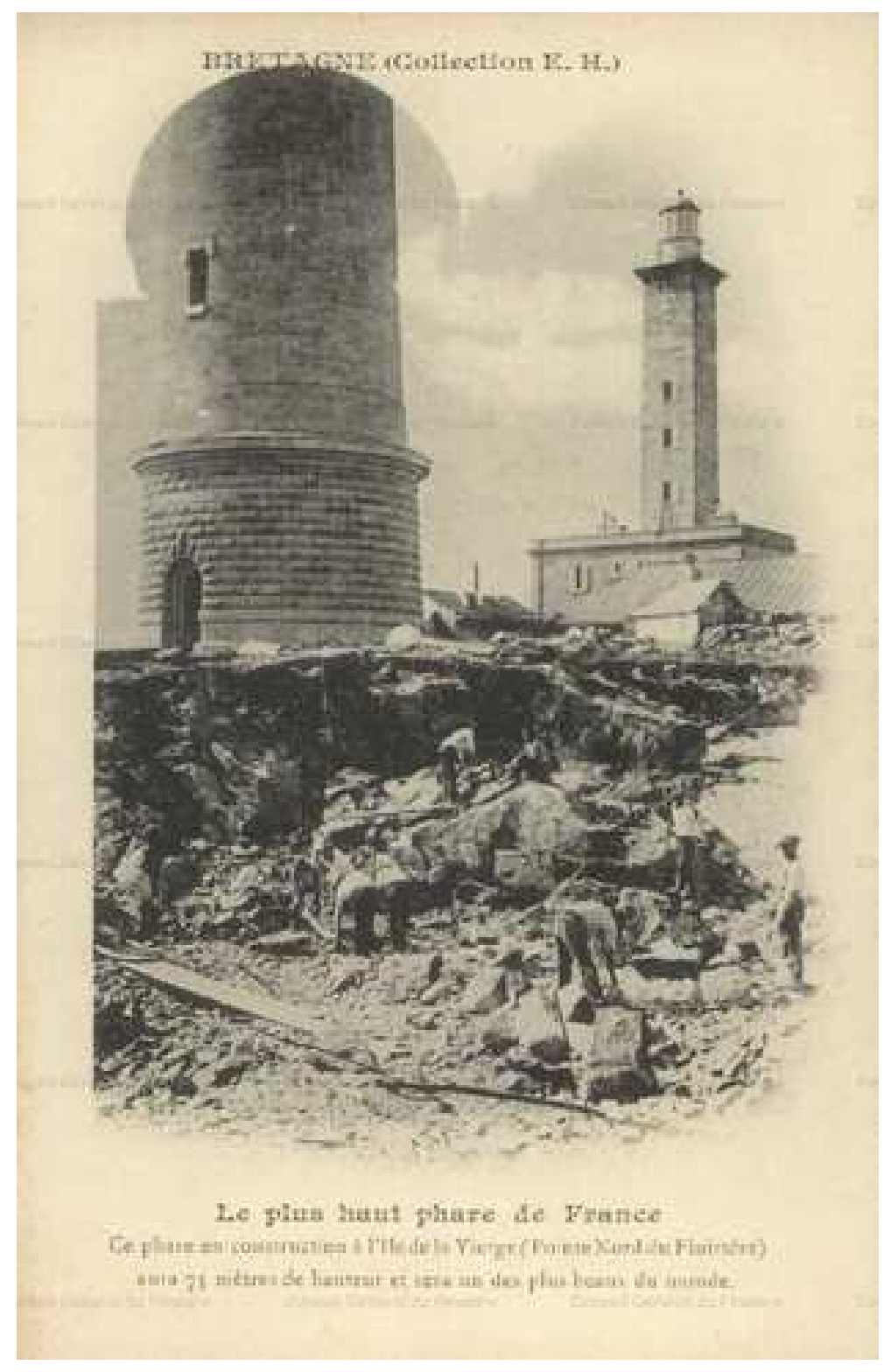

Figure 6 - Extraction of granite at the foot of the lle Vierge lighthouse [A8]

Kersantite is a grey or greenish magmatic rock found in western Brittany. It looks like granite but is not. The kersantite used for the lle Vierge lighthouse came from the quarries of Logona, close to Brest [1] [A8]. This rock was highly appreciated for the construction of lighthouses in Brittany and even beyond, as far as the lle de Ré (in the Baleines lighthouse) [7]. This rock was preferred to the local granite, despite its higher cost, because of its ability to form sharp edges and its great resistance to weathering, as evidenced by the many churches built 
with this rock in the region [A7]. The choice of kersanton for the external face of the lighthouse and granite for the inner face was not made lightly: it ensured the resistance of the construction to harsh weather conditions by putting the most durable stone on the most exposed wall facings.

(d) The mortar

The mortars were made on site, using non-salted water transported to the island (no fresh water source) with sand from the northern beaches of the island of Wrach, close to the lle Vierge [A8], and Portland cement (cement to sand ratio $=400 \mathrm{~kg} \cdot \mathrm{m}-3$ ) [A5]. Cement was preferred to lime after long discussions among the engineers, stemming from the finding that all the tall towers of the time such as those of the Calais lighthouse (55 $\mathrm{m}$ high, 1848) and the Coubre lighthouse (64m high, 1895), built with hydraulic lime mortar, are split according to a diametrical plane perpendicular to the direction of the strongest winds" [A2]. In addition, the engineers did not want a repeat of the problems that occurred on the Penmarch Lighthouse for which "when the construction progressed well, it sometimes seemed prudent to slow it down because the masonry was not hard enough" [A9].

Thus, cement was preferred in the lle Vierge, as in the Eckmühl lighthouse, to increase the stiffness of the masonry tower and avoid ovalization under wind loads, especially at early ages of the mortar. This choice was also supported by the engineer $L$. Bourdelles with regard to the dynamic action of the wind, as will be seen later (section 3.3).

(e) The foundations

Geotechnical surveys carried out on the lle Vierge before the construction started had identified a good granitic soil [A7]. The solution for the foundation works described in the technical specifications [A8] was therefore simply to sit the masonries directly on the granitic soil after excavating about $1 \mathrm{~m}$ of ground. Unfortunately, the excavation at the location of the tower brought to light a poor quality sand zone $(4 \mathrm{~m}$ wide and about $2 \mathrm{~m}$ deep), in the axis of the lighthouse, that had to be excavated (which explains the particular form of the foundations in Fig.5). There was no metal anchorage in the rock substratum.

\section{(f) The construction works}

During the 4 years of work, all the food for the workers, and all the animals (horses), materials, tools, and equipment, were delivered by boat, with the exception of granite, which was taken from the island itself [A10]. The materials arrived by boat (Fig. 7), were transported to the lighthouse by wagons pulled on rails by horses, then raised to the work platform using a winch (Fig. 8). 


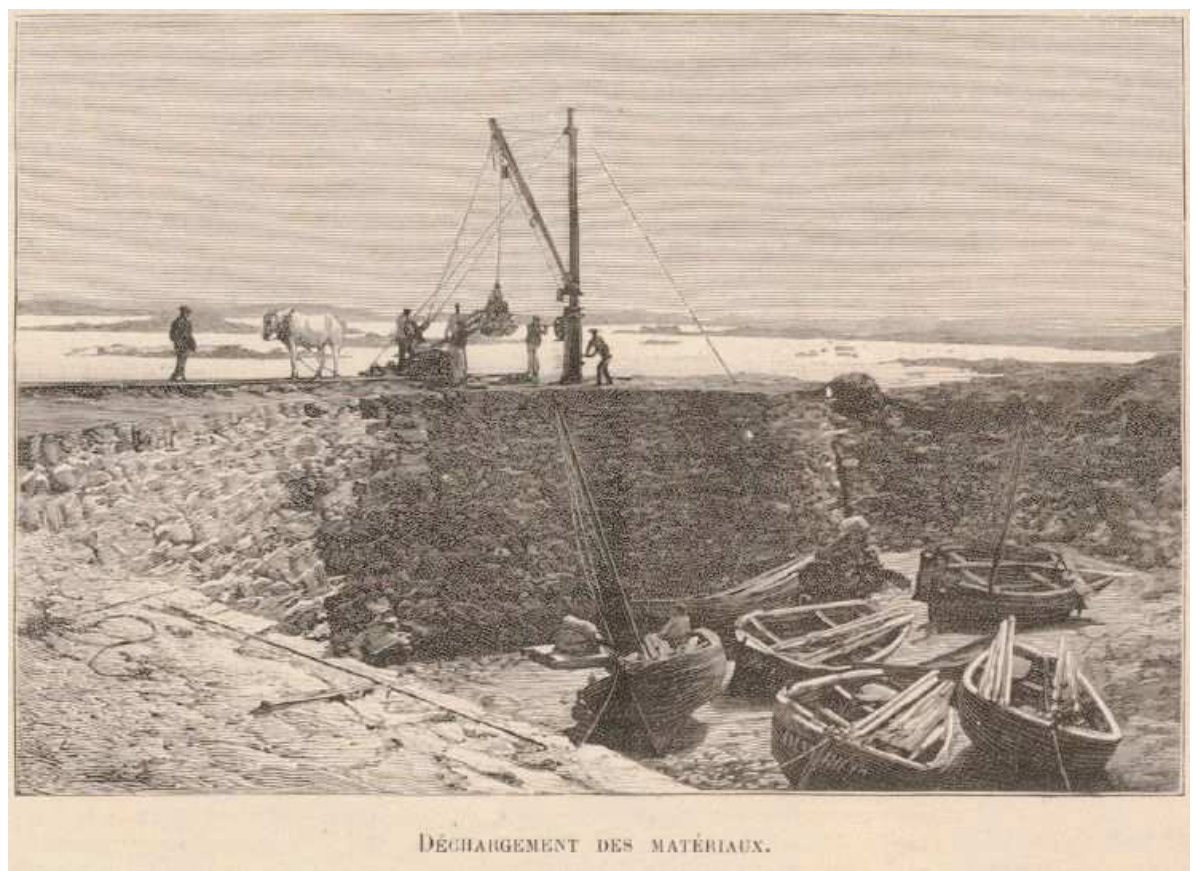

Figure 7-Loading and unloading on the lle Vierge [4]

Barracks for the masons had been built on the island by the masonry company [8] but the ordinary workers returned to the continent every evening. The working conditions on the tower were difficult, even though construction was stopped during the winter and when storms occurred. Le Goffic, a journalist and writer of the time visited the work site when the central stairs consisted of about 200 steps [4] (Fig. 8). He was impressed by the height already reached and the risks of falling from the work platform. Fortunately, there were no accidents on the lle Vierge during the construction of the lighthouse.

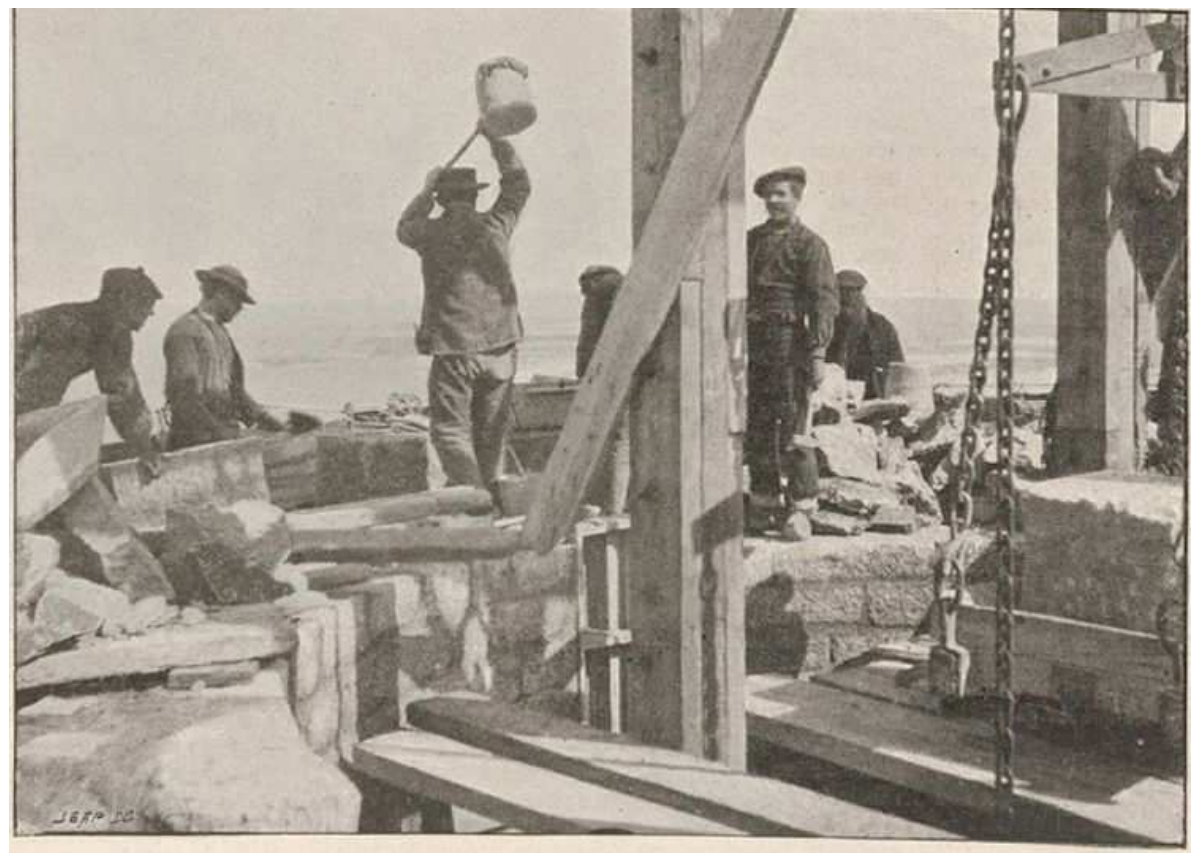

A 4 S MĖTaEs DE HAUTEUR.

Figure 8 - Construction of the lle Vierge lighthouse [4] 


\section{WIND CALCULATION DURING THE 19Th CENTURY}

(a) Static wind action

The most famous scientists mentioned in the history books for their discoveries in fluid mechanics from the $18^{\text {th }}$ to the late $19^{\text {th }}$ centuries are the mathematicians and physicians Daniel Bernoulli (1700-1782), Leonhard Euler (1707-1783), Claude Navier (1785-1836), George Stokes (1819-1903) and Osborne Reynolds (1842-1912). Those whose work is going to be discussed in this paper do not figure in this list. They were engineers who, during the $19^{\text {th }}$ century, designed buildings such as lighthouses, towers, and chimneys, very exposed to the wind. To ensure the stability, resistance and durability of these buildings, the engineers had to make assumptions about the wind pressure on the structures, perform calculations, and take responsibility for the results. Here are their names: Smeaton (1724-1792), Augustin Fresnel (1788 - 1827) and Leonor Fresnel (1786 - 1869), Rankine (1820 - 1872) and Eiffel (1832-1923). Their advances in the understanding of wind action were taught at the Ecole des Ponts et Chaussées in France throughout the $19^{\text {th }}$ century, as part of the "maritime works" course, and implemented by the successive engineers of the Service des Phares et Balises, all trained at this school. They form the basis of the first standard on wind action on structures, established at the end of the $19^{\text {th }}$ century.

\section{(i) John Smeaton}

John Smeaton, (1724 - 1792) is considered as the founder of the civil engineering profession in Great Britain. He built the Eddystone lighthouse (1756-1759) while developing a hydraulic lime mortar able to harden underwater and so was the first to understand how to constitute a hydraulic lime. On May 31, 1759, John Smeaton read the results of numerous experiments conducted to improve the efficiency of windmills [9] in front of the Royal Society of London. In particular, this work presents a table (Fig. 9) that links the wind velocity with its pressure measured on a plate perpendicular to the flow, in accordance with a scale commonly used at the time to denote the wind intensity in everyday language. 


\section{TABLE VI. Containing the Velocity and Force of Wind, according to their common Appellaticns.}

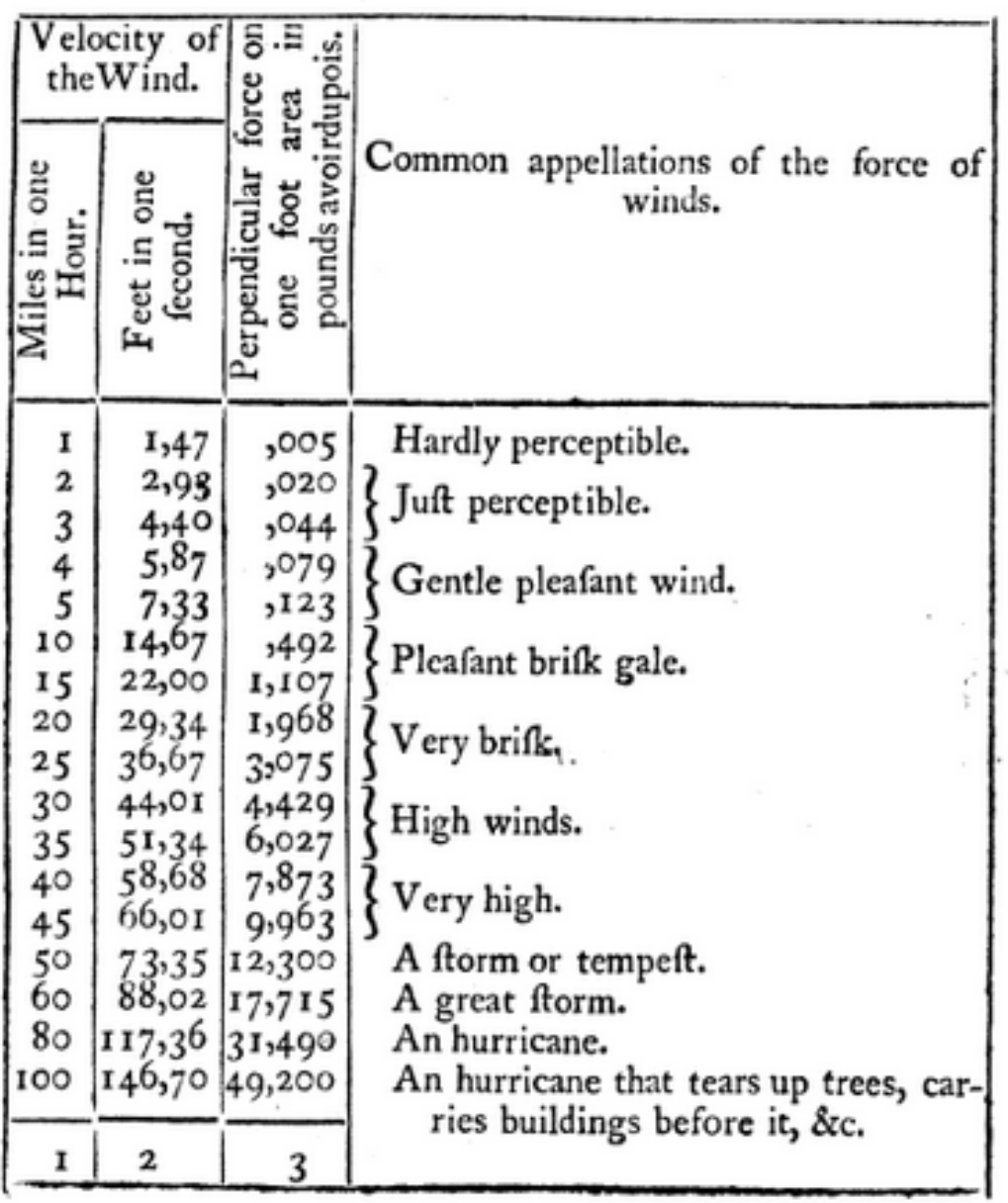

Figure 9 - Wind velocity and load according to Smeaton [9]

Smeaton took care to point out that the speed values exceeding 50 miles per hour $(80 \mathrm{~km} . \mathrm{h}-1)$ were not as reliable as the lower values because they were obtained by extrapolation of the measurements made with mean winds. This extrapolation was obtained using equation (1). Transformed into current international units $(\mathrm{N}, \mathrm{m}, \mathrm{s})$, the coefficient is equal to 1.2 which is about the density of air (2). It should be noted, however, that Smeaton never referred to the work of Daniel Bernoulli.

$P=0.0022 V^{2} \quad$ With $P$ in psf and $V$ in $\mathrm{ft.s}-1$

$P=1.2 V^{2} \quad$ With $P$ in N.m-2 and $V$ in $\mathrm{m} . \mathrm{s}-1$

\section{(ii) Augustin Fresnel}

In 1825, on the occasion of the construction of the Belle-lle lighthouse, Augustin Fresnel studied the wind action on a tower. The method he used in his calculations was reported by his younger brother, Leonor Fresnel, in 1831 [10]. Augustin Fresnel assumed the wind limit velocity to be 50 m.s-1 which "exceeds by one ninth the 
velocity of the strongest hurricanes mentioned in the yearly report of the French Bureau of Longitudes in the year 1818". Referring to the experiments reported by Smeaton 66 years earlier, he states that the maximum wind pressure to be considered on the Belle-lle lighthouse equals $2750 \mathrm{~N} . \mathrm{m}-2$ (this is actually the load for 48 m.s-1).

\section{(iii) Léonor Fresnel}

In 1831, Léonor Fresnel validated the wind pressure value chosen by his older brother Augustin, by comparing it with the notes of Navier published in the 1819 edition of Bélidor's Architecture Hydraulique [10]. He extended the calculations and established a method to verify the stability of lighthouses under wind load. The principle, in the case of a square tower, is the following: the wind moment is calculated at the 0.000 level by applying 2750 N.m- 2 to one of the faces of the tower from bottom to top. He admitted that this pressure "can be seen as greater than the maximum effort of our hurricanes". The self-weight moment, which L. Fresnel calls "moment of resistance", is obtained by multiplying the total weight of the tower by the half-width of its base. He called the ratio of these two moments "absolute stability". He acknowledged that, in his calculation, he ignored the deflection of the top of the tower, but said that this calculation (which is now called second order calculation) was not useful because the phenomenon was negligible.

This method is transposed to the case of a circular section tower by assuming that "the wind action on a vertical cylinder is reduced to $2 / 3$ of what it would be on the meridian section of the same cylinder". So, the total wind force (in Newtons) on a cylindrical tower according to L. Fresnel is given in equation (3) with the height $H$ and diameter $D$ in metres, and $V=48 \mathrm{~m} . \mathrm{s}-1$.

$F_{\text {Fresnel }}=\frac{2}{3}\left(1.2 V^{2}\right) D H$

Léonor Fresnel applied this method to several existing chimneys and lighthouses that had demonstrated stability under wind and storms for a long time (in particular the $76 \mathrm{~m}$ high Genoa tower in Italy built in 1543, the French Cordouan lighthouse built in 1611, and industrial chimneys in brick), and finally wrote that stability is ensured if the "absolute stability" is at least equal to 4 [A11].

\section{(iv) William John Macquorn Rankine}

According to Guilly in 1876, "the English may be the only ones involved in defining stability rules for tall masonry chimneys" [11]. Actually, Rankine, in A Manuel of Applied Mechanics published in 1858 [12] dedicated 4 pages to towers and chimneys.

For Rankine, as for Fresnel and Smeaton, the wind action on the construction was horizontal, uniform and only in the direction of the wind. It concerned square and round chimneys. Rankine said that the maximum wind pressure on a flat surface was 55 psf (pounds per square foot, or $2680 \mathrm{~N} . \mathrm{m}-2$ ) corresponding to a velocity of 47 m.s-1. He based this assumption, on the one hand, on the measurements carried out by means of anemometers and, on the other hand, on the feedback on existing chimneys. He did not refer to Smeaton's works. To pass from a square tower to a round tower, he chose the coefficient $1 / 2$ and not the $2 / 3$ value used by Léonor Fresnel. So, the total wind force ( $F$ in Newtons) on a cylindrical tower according to Rankine is given in equation (4) with the height $H$ and diameter $D$ in metres, and $V=47 \mathrm{~m} . \mathrm{s}-1$.

$F_{\text {Rankine }}=\frac{1}{2}\left(1.2 V^{2}\right) D H$ 
To verify the stability of the cylindrical towers, Rankine kept the same safety coefficient as Léonor Fresnel, i.e. 4 , but used only 3 for the square towers [12].

\section{(v) Gustave Eiffel}

The wind action taken into account by Eiffel [13] when calculating the Garabit viaduct, built in 1880 in France, was $2700 \mathrm{~N} . \mathrm{m}^{-2}$ when the bridge was not loaded with trains and $1500 \mathrm{~N} . \mathrm{m}-2$ otherwise. For the famous tower he built in Paris (1889), he chose to vary the wind pressure from 2000N.m-2 on the ground to $4000 \mathrm{~N} . \mathrm{m}-2$ at the top of the tower. In his calculation notes for the $300 \mathrm{~m}$ tower [14], Eiffel gave an equation similar to (2) as "generally accepted", and which is the one proposed by Smeaton 130 years earlier. He discussed the validity of this equation with respect to the measurements carried out on his tower, and proposed a coefficient 0.9 instead of 1.2 for the calculation of the metal frame.

\section{(vi) First standardization in France}

The first French Standard on wind action to be taken into account on structures was the "Circulaire du Ministre des Travaux Publics" dated August 29, 1891 [15]. It added wind action to the previous texts of 1858 and 1877, which considered only gravity actions. This circular imposed exactly the assumptions that Eiffel had applied for the calculation of the Garabit bridge 10 years earlier. The calculation assumptions of neighbouring European countries, at the same time, were similar, as Schueremans points out [16].

\section{(b) Dynamic wind action}

The vibration of lighthouses and chimneys under wind action was known by the $19^{\text {th }}$ century engineers. It was taught by De Rochemont in 1897 in the Ecole des Ponts et Chaussées that the wind action could determine oscillations able to harm the working of optical apparatus [6].

Fresnel noted [10] that the towers "experience in storms similar oscillations to the swinging of trees". These oscillations result from the "elasticity of the building and the intermittent wind." He evaluated the period of these oscillations at 2 seconds. On the towers he inspected, he observed no damage that could come from these oscillations and concluded that the oscillations caused by storms could not compromise the lighthouses, if of good construction, i.e. if their "absolute stability" was greater than 4.

In 1864, [17] Léonce Reynaud, Director of the Service des Phares et Balises from 1846 to 1878 warned against the effect of oscillations, which had indeed been observed in most lighthouses over $40 \mathrm{~m}$. He observed that, because of the oscillations of the tower, the liquid contained in vases overflowed, the motor weights of the optical machine hit the walls, and a few people suffered effects similar to those on a rolling boat. Reynaud specifies that oscillations do not cause a failure of the towers, nor any "spall in the edges of the stones, opening of joints, cracks on wall facings".

However, he recommends sizing the towers with a safety coefficient of 5 under a wind action of 2750 N.m-2 on a flat surface normal to the wind direction (instead of 4 for Fresnel) to prevent these oscillations. It has nothing to do with the resistance of the masonry structures but can affect the correct functioning of the optical machines and the comfort of the keepers.

To sum up, the dynamic effects on tall towers were known to $19^{\text {th }}$-century engineers but, without any available formulation or calculation model, they used safety factors between 3 and 5 in their designs. On the occasion of the construction of the lle Vierge lighthouse, the question of the oscillations was the subject of debates, as will be seen in next section. 


\title{
4 WIND ON ILE VIERGE LIGHTHOUSE
}

\author{
(a) Calculations in 1897
}

The stability of the lle Vierge lighthouse under wind load was calculated by the engineer De Joly, of the Service des Phares et Balises, according to the approach of Léonor Fresnel.

This calculation was checked in 1897 [A11] by the engineer Bourdelles, Director of the Service des Phares et Balises. In Paris on June 29, 1896, De Joly wrote that he was not at all anxious about the stability of the tower after comparing the calculation assumptions with those used by Fresnel and Rankine [A2]. The stability scheme attached to the project [A11] established that the tower was not exposed to any tension stresses, that the maximum compression stress due to the wind load and the self-weight of the masonry (calculated with a density of $2400 \mathrm{~kg} \cdot \mathrm{m}^{-3}$ ) did not exceed $1.05 \mathrm{MPa}$, and that the stress on the ground was less than $0.7 \mathrm{MPa}$, which remains below the limit set by the engineers (1.2MPa [A5]). The "absolute stability" defined by Fresnel and calculated by Bourdelles for the lle Vierge lighthouse was 10.8 "which should offer all desirable guarantees, especially in comparison with the coefficients of the tallest existing lighthouses".

However, Bourdelles worried about the effect of oscillations that could hamper the operation of the optical apparatus. He contested the opinion that "the dynamic effects of gusts can be calculated by a static model"[A12]. He recalled that "tall lighthouses experience oscillations that have a magnitude large enough to paralyze the optical apparatus during storms."

Based on his observations of existing lighthouses, Bourdelles attributed the good behaviour of the towers under dynamic wind load to the "good quality of the material, which increases their stiffness". For the lle Vierge lighthouse, he therefore agreed with the use of Portland cement rather than lime, and insisted on "the care that must be taken in the construction of the masonry especially in the upper part of the tower", even voicing the thought that it would be appropriate to "increase the cement ratio in the mortars in this part " [A12]. In response, the engineer Considère, in charge of the work on site, supported this point of view.

At the end of the construction of the lle Vierge lighthouse, it was decided, at the request of Ribière, Head Engineer of the Service des Phares et Balises, to measure the oscillations of the tower using the oscillograph developed by Richard in 1904 (Fig.10). A scientific article of 1905 [18] reported that "at the new lle Vierge lighthouse, the highest in the world and whose tower has a very high stiffness, the oscillograph revealed no perceptible movement in the strongest storms". The period measured thanks to this new equipment was 0.775 seconds [19]. It was therefore accepted by the engineers that "by giving great stiffness to the towers, the oscillations, even in the strongest storms, can be made imperceptible, as at the lle Vierge lighthouse".

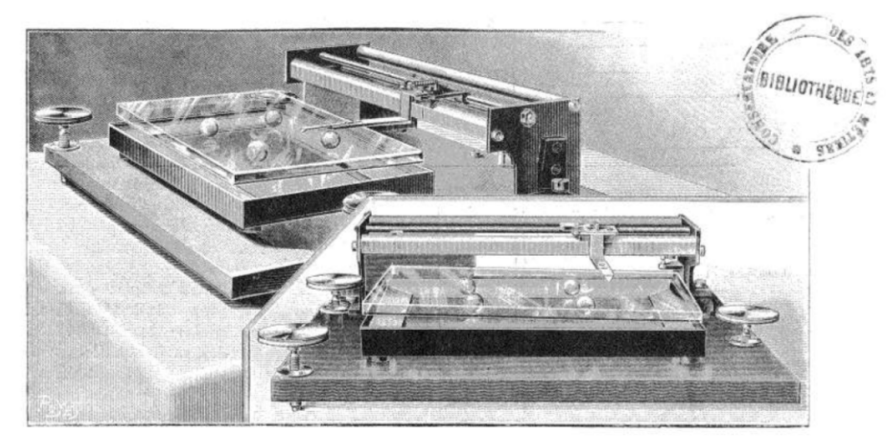

Figure 10 - Richard's oscillograph [18]. 
To sum up, in the $19^{\text {th }}$ century, it was considered that the ratio between the wind pressure (in N.m-2) on a square plate and the square of the wind velocity (in m.s-1) was equal to 1.2 . A coefficient of $1 / 2$ (for Rankine) or $2 / 3$ (for Fresnel) was applied to obtain the wind pressure on a cylindrical tower, whatever its height, diameter and materials. The maximum wind velocity taken into account was $47 \mathrm{~m} . \mathrm{s}-1$. In the case of the lle Vierge lighthouse, $80 \mathrm{~m}$ high and with a mean diameter of $9.60 \mathrm{~m}$, the total wind force equalled $1408 \mathrm{kN}$ for Fresnel and $1029 \mathrm{kN}$ for Rankine, while the wind velocity was similar. A safety coefficient of 4 was applied for the verification of stability in order to prevent the optical apparatus from being stopped in case of storms. The design of the tower was therefore linked, not to the masonry strength, but to the proper functioning of the optical apparatus.

Eurocode 1

Reynolds' experiments in 1883 that highlighted the laminar-turbulent transition were not immediately applied to the calculation of lighthouses and chimneys. In 1921, Custodis, the first manufacturer of industrial chimneys in the USA, wrote that the determination of the wind pressure on a chimney remained a controversial subject, because this pressure could only be determined by empirical measurements and no theoretical law on the air flow impacting an object was known [20]. Therefore, the method used at the beginning of the $20^{\text {th }}$ century, as in the previous century, to determine the wind force for any cylinder was to apply a correction coefficient to the wind pressure on a flat surface, according to Equation (2) resulting from Smeaton's measurements.

However, as a result of the development of aviation, aerodynamics knowledge developed considerably between 1890 and 1920. Wind tunnel tests developed throughout Europe. Meetings of the most advanced scientists in this field were organized from 1921 in order to standardize their experimental methods and the formulation of equations [21].

Since this work was completed, in 1923, the wind pressure on a structure has been obtained by applying a dimensionless coefficient " $C$ " to the dynamic pressure of the wind q, equal to $\frac{1}{2} \rho V^{2}$, where $\rho$ is the air density $(1.225 \mathrm{~kg} . \mathrm{m}-3)$ and $V$ the wind velocity far upstream of the structure. The standards provide a method for determining $C$. These methods are derived from experimental research that has revealed the parameters involved in the wind pressure on a structure and what was hidden in the Fresnel and Rankine coefficients.

In Eurocode 1-4 [22], the wind force $F$ acting on a structure may be determined directly by using expression:

$F=C_{s} C_{d} \cdot C_{f} \cdot q_{p} \cdot A_{\text {ref }}$

Where $C_{s} C_{d}$ is the structural factor, $C_{f}$ is the force coefficient for the structure, $q_{p}$ is the peak velocity pressure and $A_{r e f}$ is the reference area of the structure. To simplify the calculation, the windows and openings in the lighthouse have been neglected. The calculation was carried out with $H=80 \mathrm{~m}$ and $D=9.60 \mathrm{~m}$ (mean value). Here, $C_{s} C_{d}=1$ and $A_{\text {ref }}=H D$.

\section{(i) Peak velocity pressure}

The basic wind velocity corresponding to an average return period of 50 years in the Finistère is $V_{b}=$ $26 \mathrm{~m} . \mathrm{s}^{-1}$ and so the basic pressure is $q_{b}=\frac{1}{2} \rho V_{b}^{2}=414 \mathrm{~N} \cdot \mathrm{m}^{-2}$. The mean velocity is $V_{m}=C_{r} C_{0} V_{b}=$ $40.7 \mathrm{~m} . \mathrm{s}^{-1}$ where $C_{r}=1.565$ and $C_{0}=1$. The mean pressure is $q_{m}=\frac{1}{2} \rho V_{m}^{2}=1014 \mathrm{~N} . \mathrm{m}^{-2}$. 
The peak velocity pressure formula is $q_{p}=\left[1+7 I_{v}\right] \frac{1}{2} \rho V_{m}^{2}$ where the turbulence intensity is $I_{v}(80 m)=$ 0.103 and the standard deviation of velocity $I_{v} \cdot V_{m}=4 m \cdot s^{-1}$. Finally, the peak velocity pressure is $q_{p}=$ $1750 \mathrm{~N} . \mathrm{m}^{-2}$ with a peak velocity $V_{p}=53.5 \mathrm{~m} . \mathrm{s}^{-1}$.

\section{(ii) Force coefficient}

For a finite circular cylinder, Eurocode $1 C_{f}$ is calculated as (6) (EC1-1-1 Expression 7.19).

$C_{f}=C_{f, 0} \cdot \psi_{\lambda}$

$C_{f, 0}$ is the force coefficient of cylinders without free-end flow. It depends on the Reynolds number $R_{e}$ (here $3.10^{7}$ ) and on the equivalent roughness $k / D$. Here $k=1 \mathrm{~mm}$ (granite masonry equivalent to rough concrete). Hence $C_{f, 0}=0.9$.

The end-effect factor $\psi_{\lambda}$ is a function of solidity ratio $\varphi(\varphi=1)$ versus slenderness $\lambda=2 H / D$ (EC1 - French National Annex). Here $\lambda=17, \psi_{\lambda}=0.75$ (EC1 Figure 7.36).

Finally $C_{f}=0.67$.

The total wind force in the direction of the wind, applied on the lle Vierge lighthouse is $900 \mathrm{kN}$. For comparison, $F_{E C 1}$ (in Newton) can be expressed by formula (7), with the height $H$ and diameter $D$ in metres, and $V=53.5 \mathrm{~m} . \mathrm{s}-1$.

$F_{E C 1}=0.41 V^{2} D H$

This is the static wind action. With EC1 (Annex E), structural vibrations may occur if the frequency of vortexshedding is the same as a natural frequency of the structure. The effect of vortex shedding need not be investigated when the critical wind velocity is higher than 1.25 times the mean wind velocity, which is true in the case of the lle Vierge lighthouse.

(c) Comparison

Table 1 shows a synthesis of the equations of Smeaton, Fresnel, Rankine, Eiffel and EC1, and the equivalent drag coefficient for cylinders calculated as $C_{D}=\frac{F}{q_{p} A_{r e f}}\left(\mathrm{SI}\right.$ units. $\left.A_{\text {ref }}=D H\right)$.

Table 1 - Comparison of drag coefficient

\begin{tabular}{|l|l|l|c|c|}
\hline & Year & Shape & Equation $[\mathrm{SI}]$ & $C_{D}$ \\
\hline Smeaton & 1759 & Flat plate & $P=1.2 V^{2}$ & \\
\hline Fresnel & 1831 & Cylinder & $F=\frac{2}{3}\left(1.2 V^{2}\right) D H$ & 1.3 \\
\hline Rankine & 1858 & Cylinder & $F=\frac{1}{2}\left(1.2 V^{2}\right) D H$ & 1.0 \\
\hline Eiffel & 1900 & Eiffel tower & $P=0.9 V^{2}$ & \\
\hline Eurocode 1 & 1991 & Cylinder & $F=C_{s} C_{d} \cdot C_{f} \cdot q_{p} \cdot A_{\text {ref }}$ & 0.67 \\
\hline
\end{tabular}


The total wind forces on the lle Vierge lighthouse, calculated with Fresnel, Rankine and EC1 are $1408 \mathrm{kN}$, $1029 \mathrm{kN}, 900 \mathrm{kN}$, respectively. Looking at these figures, one could think that Fresnel and Rankine made more conservative calculations than EC1. However, it is necessary to remind that, with Eurocode, two Ultimate Limit States are to be considered: the EQU Equilibrium Limit State and the STR Strength Limit State. In both cases, the wind action $W$ is increased by $50 \%\left(\gamma_{Q, 1}=1.5\right)$, which gives an action of $1.5 \times 900=1350 \mathrm{kN}$, a value between those of Fresnel and Rankine. In addition, a reduction factor $\gamma_{G, i n f}=0.9$ is applied for unfavourable permanent action so as the self-weight here. The stabilizing moment was calculated by De Joly in 1897 taking account of a masonry density equal to $2400 \mathrm{~kg} \cdot \mathrm{m}^{-3}$ while the real value of masonry density is around $2600 \mathrm{~kg} . \mathrm{m}^{-}$

${ }^{3}$ (granite and kersanton cut stone masonry). So, with regard to the stability of the tower, the old and current calculations present similar values and lead to the same conclusion: no risk of failure.

Moreover, the value of the critical wind velocity in regards of vortex shedding, calculated with EC1, highlights that the lle Vierge lighthouse does not present a risk of vibratory phenomena, which had been demonstrated by the measurements carried out at the end of its construction using Richard's oscillograph. Actually, the dimensions of the lighthouse were chosen by the engineers for this purpose: to prevent any oscillation that would lead to its shutdown. In today's language: to ensure serviceability.

\section{CONCLUSION}

The research presented here highlights the working methods of $19^{\text {th }}$ century engineers involved in the design and construction of lighthouses in France. They chose the materials and the dimensions of the towers with great care in order to guarantee good progress of the construction, as well as the safety and durability of the structure. The construction of the lle Vierge lighthouse during the last years of the $19^{\text {th }}$ century gained from the feedback and the knowledge acquired by the French and English engineers over the century.

With regard to the wind action, the calculation method remained the same throughout the $19^{\text {th }}$ century. It was based, on the one hand, on the wind pressure measurements presented by Smeaton in England in 1759 and, on the other hand, on the application of a shape coefficient to take the cylindrical shape of the structure into account. Engineers such as the Fresnel brothers, Rankine and Eiffel kept the wind velocity and pressure values presented by Smeaton in 1759, as did all French engineers trained at the Ecole des Ponts et Chaussées in France, and, in particular, the Service des Phares et Balises engineers. The construction of lighthouses and towers throughout the $19^{\text {th }}$ century finally provided a practical validation, at the scale of the structure, of experimental research carried out in the $18^{\text {th }}$ century on a reduced sample. The first standards, in France as in England, came into being at the end of the $19^{\text {th }}$ century, and formalized the wind load that all these engineers were already used to employing.

Research carried out in the $20^{\text {th }}$ century provided a better understanding of the parameters involved in the wind action. All the lighthouses were designed with high safety coefficients (10 in the case of the lle Vierge lighthouse) which led to oversizing of the towers. The aim of the engineers was to prevent oscillations appearing that could cause a dysfunction of the optical apparatus. In other words, their goal was to ensure serviceability in all types of weather.

Overall, this historical research shows that the designers of lighthouses in the $19^{\text {th }}$ century had the same objectives as engineers today: to build resistant, sustainable structures in which deformations under loads remain compatible with serviceability. 


\section{FINISTÈRE DEPARTMENTAL ARCHIVES, FRANCE}

A1. 25S art. 233. Projet C.3. Phare de l'ile vierge. Modification de l'éclairage. Reconstruction de la tour. Rapport de l'ingénieur ordinaire. Signé Pigeaud le 8 janvier 1897.

A2. 25S art. 233 Courrier signé de l'ingénieur ordinaire, G de Joly, Paris, le 29 juin 1896.

A3. 36Fl68 Photo Archives du Finistère, Photothèque, photo aérienne de l'ile Vierge

A4. IC 27 - 2012 Photo Archives du Finistère, Photothèque, photo aérienne de la tête du phare de l'ile Vierge. A5. $25 \mathrm{~S}$ art. 233. Courrier " transformation du phare de l'ile vierge. Exécution de la décision ministérielle du 22 avril 1896 ", signé de l'ingénieur ordinaire, G de Joly, Paris, le 13 juin 1896.

A6. $25 \mathrm{~S}$ art. 231. Elévation et coupe de la tour en maçonnerie.

A7. 2FI195/54 Photo de l'extraction du granite sur l'ile vierge. Archives du Finistère, Photothèque — sans date.

A8. 25S art. 235. Cahier des charges dressé par l'ingénieur ordinaire à Brest le 8 janvier 1897.

A9. $25 \mathrm{~S}$ art. 233. Rapport de l'ingénieur en chef, M. Considère Quimper, le 03 novembre 1896.

A10. $25 S$ art. 233. Projet $n^{\circ} 3$. A.3. Phare de l'ile vierge. Modification de l'éclairage. Reconstruction de la tour. Détail estimatif des travaux. Signé Pigeaud, Brest le 8 janvier 1897.

A11. $25 \mathrm{~S}$ art. 233. Extrait du rapport de l'inspecteur général, directeur du service des phares et balises en date du 13 février 1897. Stabilité de la tour.

A12. Ministère des travaux publics, Phares et Balises, Finistère, phare de l'ile vierge. Reconstruction. Courrier de M. Bourdelles à M. Considère, Paris le 17 mars 1897.

\section{REFERENCES}

1. H. Desmarest. 1901. Le phare de l'ile vierge. Revue Universelle. Paris.

2. A. Da Cunha. 1902. Le phare de l'lle Vierge. La Nature. Paris. $1^{\text {st }}$ semester 1902.

3. Lighthouses of France: Northern Finistère. Université de Caroline du Nord. Consulted $17^{\text {th }}$ October 2018. http://www.ibiblio.org/lighthouse/fns.htm.

4. C. Le Goffic. 1897. Le plus haut phare de France. Le monde illustré.

5. E. Allard. 1889. Les phares, histoire, construction, éclairage. Paris. Ed. J. Rothschild.

6. E.T. Quinette de Rochemont, H. Desprez. 1891. Cours de travaux maritimes. Bibliothèque numérique patrimoniale des ponts et chaussées, accessed 2018/12/19. Https://patrimoine.enpc.fr/document/ENPC02_COU_4_20654_1896_1.

7. L. Chauris. 1998. Construction d'un phare en mer d'Iroise : les pierres Noires (1866-1872). Annales de Bretagne et des Pays de l'Ouest. Tome 105, n¹, 71-89 (https://doi.org/10.3406/abpo.1998.3973)

8. C. Le Goffic. 1899. Les métiers pittoresques. Le plus haut phare de France. Paris : Fontemoing.

9. J. Smeaton. 1796. Experimental enquiry concerning the natural powers of wind and water to turn mills and other machines. London, I. \& J. Taylor, 1796, 2nd edition. Also published in Paris in 1810.

10. L. Fresnel. 1831. Mémoire sur la stabilité du phare de Belle-île en mer. Annales des Ponts et Chaussées. Paris, Carilian-Goeury Ed. 1831, $2^{\text {nd }}$ semester. Pp. 385-420.

11. A. Gouilly. 1876. Théorie sur la stabilité des hautes cheminées en maçonnerie. Paris : J. Dejey \& Cie.

12. W.J. Macquorn Rankine. 1858. A manual of applied mechanics. London and Glasgow: Richard Griffin and Company.

13. G. Eiffel. 1889. Mémoire présenté à l'appui du projet définitif du viaduc de Garabit. Paris, Baudry et Cie.

14. G. Eiffel. 1900. La tour de trois cent mètres. Paris, Soc. des imprimeries Lemercier, Baudry et Cie. June 1, 1900.

15. Circulaire du Ministre des Travaux Publics aux préfets, 29 aout 1891. Révision de la circulaire ministérielle du 9 juillet 1877. Nouveau règlement relatif aux épreuves des ponts métalliques. Instructions pour l'application de ce règlement.

16. L. Schueremans, H. Porcher, B. Rossi, I. Wouters. 2018. On the evolution in design and calculation of steel structures over the $19^{\text {th }}$ century in Belgium, France and England. Int. J. of Architectural Heritage. 2018. Vol. 12, 320-333 (https://doi.org/10.1080/15583058.2017.1323244)

17. L. Reynaud. 1864. Mémoire sur l'éclairage et le balisage des côtes de France, Paris : imprimerie impériale. 18. R. Bonnin. 1905. Les oscillations des tours de phare. La Nature. July 15, 1905. Pp. 97-98. 
19. Ribière. 1904. Oscillations des tours des phares. Annales des Ponts et Chaussées. September 10, 1904.

20. Alphons Custodis Chimney Construction Co. 1921, july. Custodis chimneys. Radial Brick Chimneys. New York.

21. Knight, Prandtl, Von Karman et al. 1923, March. Standardization and aerodynamics, Technical notes, National advisory committee for aeronautics.

22. NF EN 1991-1-4 and NA. March 2008. Eurocode 1. General Actions. Wind Actions. 